\title{
生野錫製錬所概要について
}

\section{The Outline of Ikuno Tin Smelter}

\author{
古川博 之* \\ Hiroyuki FURUKAWA
}

\section{1. 緒言}

生野製鍊所は兵庫県にあり，姫路より播但線にて北上 すること $44 \mathrm{~km}$, 中国地方のほぼ中央部, 分水䫁に当り, 海抜 $300 \mathrm{~m}$ に位置する三菱金属鈗業生野鉱業所に付属す る錫製錬所である。

昭和 9 年錫製錬設備の新設に伴い，錫鉣熔錬女又射煀 方式とし，主として明延鉱山（当時生野鉱山の支山）産 出の錫鉱を処理して来たが，第二次大戦後鉱量激減に伴 い, 昭和25年錫熔鍊方式を電気炉に変更, 縮少生産在行 ない, 以後逐年操業も安定, 再び增処理に努力し現在に いたつている。

当製錬所は敷地面積約 $7,000 \mathrm{~m}^{2}$, 建屋面積約 $4,500 \mathrm{~m}^{2}$, 直接製鍊従業員約56名（補助，管理，事務要員泼除く） の小規模製鍊所である。本文では錫製鍊の操業現況と設 備の改善, 操業合理化等 2,3 の改善例を，最後に当製鍊 所の今後の問題点について少しふれてみたい。

\section{2. 操 業 現 況}

当所に入荷する錫鉱は，普通，酸化焙燒後，脱タング ステンのためンーダ焙焼を行ない，錫鉱中に含有するタ ングステンを温湯抽出除去する。これは副産品として回 収方る一方，抽出錫鉱はエルー式電気炉による還元熔解 老行なら。

錫鉱の還元熔解に際しては鉱石吹き, カラミ吹き等,

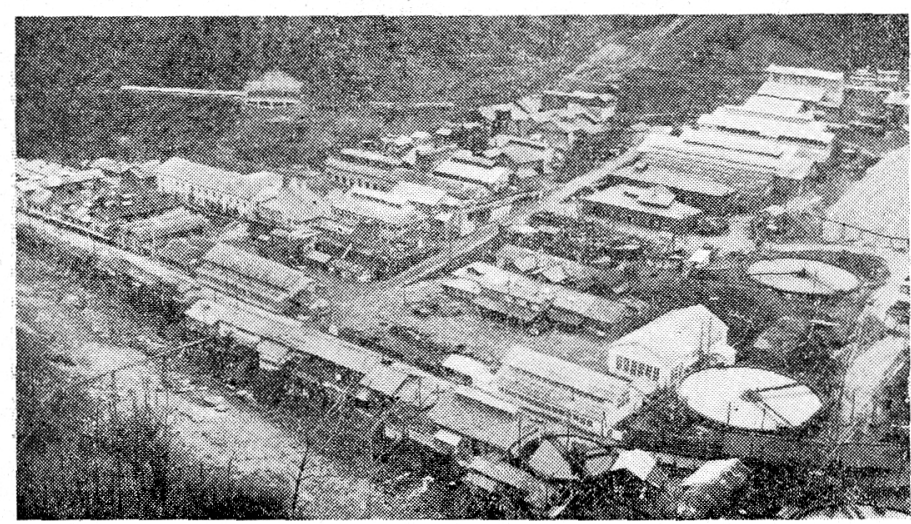

写真1 生野鉣業所全景

* 三菱金属鈗業株式会社生野鉱業所製鍊課長

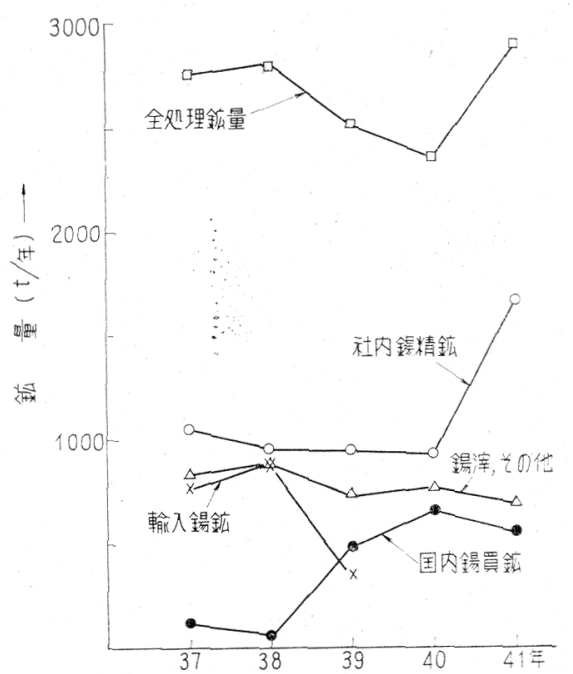

第 1 図熔錬原料の推移

2 工程以上をあらかじめ考慮して操業することが望まし いので ${ }^{1}$, 当所の電気炉熔解で梳鉱石吹き，力ラミ吹き， シリコン吹きの3 工程老採用し独特の操菜老行なつてい $ろ^{2)}$ 。第 1 図にここ 5 年閒の熔錬原料の推移を, 第 1 表 に主製品, 副産品の生産量の推移を表わした。また写真 1 は当製鍊所全景を，また第2 図に現状のフローシート と，これに主要機械設備の模様も併記しておいた。第 2 表には最近の製鍊原料, 中間製品, 製品の分析例圭示し t。

ロータリーキルンによる焙焼は錫精鉱 の脱硫，脱砣老主目的とするが，煙塺室 中の低温側で回収される烓燒煙圧は, Sn $15 \%$, As 30\%程度の比較的高含As の錫 煙灰で，これは別に積み置き，6力月に 1 回程度砒素焙焼を行ない, 粗砒または 精砒 $\left(\mathrm{As}_{2} \mathrm{O}_{3} 96 \%\right.$ 以上)を副産品として回 収する一方，焼鉣注錫熔鍊原料仙する。

電気炉装入原料の調合は, 従来加容 積調合を行なつているが，錫精鉱の他， 珪砂，石灰石等の熔剂，ならびに還元剤 等をおのおのベルト輸送，ミキサーにて 混合後バケットエレベータにて電気炉装 
第1表 主製品扣よび副製品生産量の推移

\begin{tabular}{|c|c|c|c|c|c|c|c|c|c|c|}
\hline & 和 & 37 年 & 38 & 年 & 39 & 年 & 40 & 年 & 41 & 年. \\
\hline & 量 & 品 & 量 & 位 & 量 & 位 & 量 & 品 & 量 & 品 位 \\
\hline 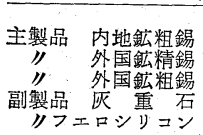 & $\begin{array}{c}1,142 \\
414 \\
37 \\
126 \\
202\end{array}$ & \begin{tabular}{|c|}
$97.24^{\%}$ \\
99.96 \\
98.76 \\
$\mathrm{WO}_{3} 78.17$ \\
-
\end{tabular} & $\begin{array}{r}1,209^{\mathrm{t}} \\
387 \\
28 \\
166 \\
184\end{array}$ & $\begin{array}{c}97.59^{\%} \\
99.96 \\
98.69 \\
77.74 \\
-\end{array}$ & $\begin{array}{r}1,278^{\mathrm{t}} \\
- \\
\overline{174} \\
251\end{array}$ & $\begin{array}{r}97.34^{\%} \\
- \\
77.71 \\
-\end{array}$ & $\begin{array}{r}1,143^{\mathrm{t}} \\
- \\
\overline{71} \\
291\end{array}$ & $\begin{array}{c}97.63^{\%} \\
- \\
- \\
76.12 \\
-\end{array}$ & $\begin{array}{r}1,325^{\mathbf{t}} \\
- \\
- \\
80 \\
321\end{array}$ & $\begin{array}{r}97.10^{\%} \\
- \\
74.31 \\
-\end{array}$ \\
\hline
\end{tabular}

第 2 表 製鍊原料，中間製品，製品の分析例

\begin{tabular}{|c|c|c|c|c|c|c|c|c|c|c|c|c|}
\hline 成 分 & $\mathrm{Cu}$ & $\mathrm{Pb}$ & $\mathrm{Zn}$ & $\mathrm{Sn}$ & $\mathrm{Fe}$ & $\mathrm{SiO}_{2}$ & $\mathrm{Al}_{2} \mathrm{O}_{3}$ & $\mathrm{MgO}$ & $\mathrm{CaO}$ & As & $S$ & $\mathrm{WO}_{3}$ \\
\hline 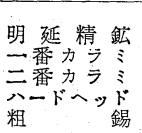 & $\begin{array}{l}0.1^{\%} \\
0.05 \\
0.01 \\
0.15 \\
0.79\end{array}$ & $\begin{array}{l}0.04^{\%} \\
0.02 \\
0.01 \\
0.01 \\
0.38\end{array}$ & $\begin{array}{l}\% \\
0.07^{\%} \\
4.27 \\
0.49 \\
0.12 \\
-\end{array}$ & $\begin{array}{c}59.07^{\%} \\
15.90 \\
0.70 \\
45.71 \\
97.65\end{array}$ & $\begin{array}{c}7.3^{\%} \\
19.54 \\
5.21 \\
44.24 \\
0.13\end{array}$ & $\begin{array}{c}2.59^{\%} \\
27.95 \\
40.01 \\
2.24 \\
-\end{array}$ & $\begin{array}{c}1.60 \\
4.59 \\
8.07 \\
0.58 \\
-\end{array}$ & $\begin{array}{c}1.17^{\%} \\
1.61 \\
1.68 \\
0.96 \\
-\end{array}$ & $\begin{array}{c}0.60^{\%} \\
2.26 \\
25.05 \\
0.12 \\
-\end{array}$ & $\begin{array}{l}0.52^{\%} \\
0.04 \\
0.04 \\
0.08 \\
0.15\end{array}$ & 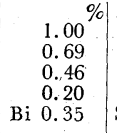 & $\begin{array}{l} \\
\\
2.70 \\
0.84 \\
0.37 \\
1.69 \\
\text { Sb } 0.34\end{array}$ \\
\hline
\end{tabular}

金易精鉱
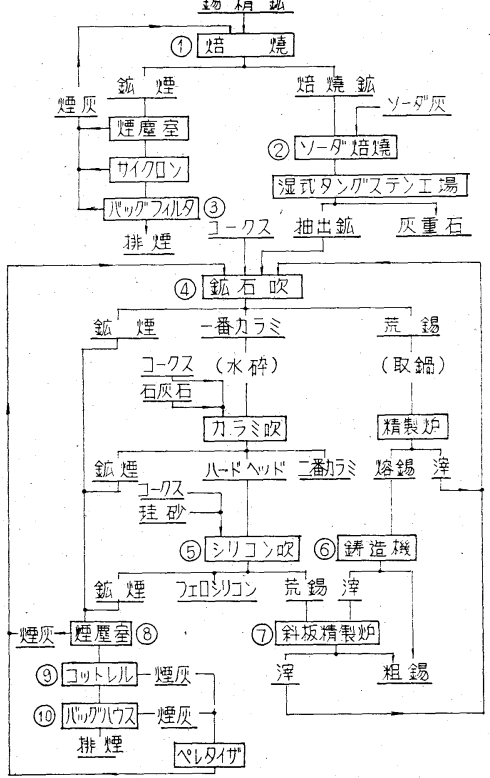

付 記

(1)ロータリーキルン:

$920 \mathrm{~mm} \mathrm{D} \times 10,680 \mathrm{~mm} \mathrm{~L}$ 内容積 $7.1 \mathrm{~m}^{3}$, 傾斜 $6^{\circ}$, 回転 $1 \mathrm{R} / 63 \mathrm{sec}$

(2)ロータリーキルン:

$1,875 \mathrm{~mm} \mathrm{D} \times 18,290 \mathrm{~mm} \mathrm{~L}$ 内容積 $50 \mathrm{~m}^{3}$, 傾斜 $5^{\circ}$, 回転 $1 \mathrm{R} / 70 \mathrm{sec}$

(3)パッグフィルタ：バッグ $300 \phi \times$ $3,000 \mathrm{~mm} \mathrm{~L} \times 15$ 本 沪過面積 $40 \mathrm{~m}^{2}$, 吸引フアン $20 \mathrm{PP}$ $50 \mathrm{~m}^{3} / \mathrm{min} 700 \mathrm{~mm} / \mathrm{WG}$

(4)No.1 電気炉: 3 相エルー式電気 炉, 円形密閉式 内径 $1,800 \mathrm{~mm} \times$ 高 $1,400 \mathrm{~mm}$, 内容積 $35 \mathrm{~m}^{3}$

内張：底，天井，側壁=シャモ ットレン゙ガ, 電極 $10^{\prime \prime}$ 人造黑釦 電極, 升降柱による固定式

(5) No2 電気炉: 3 相エルー式電気 炉, 円形密閉式

内徍 $1,600 \mathrm{~mm} \times$ 高さ $1,200 \mathrm{~mm}$ 内容䅣 $2.4 \mathrm{~m}^{3}$

内張：底, 天井二シャモットレ ソガ，側壁=シャモットクロマ

(6)鋳造機：D37m，回転連続式 鋳型本数 35 本/回転,

速度 $96 \mathrm{~mm} / \mathrm{sec}$

鋳込方式 ポンプ吸上け゚，

(7)斜板精製炉: 炬床面筫 $2,100 \mathrm{~mm}$ $\times 1,300 \mathrm{~mm}$, 炉床傾斜 $7^{\circ}$

(8)虚塵室 : $10 \mathrm{~m} \times 4 \mathrm{~m} \times$ 高さ $2 \mathrm{~m}$ ，耐 火レンガ積

(9)コットレル：金属平板電㽷式 $2,400 \mathrm{~mm}$

$2,400 \mathrm{~mm} \times 1,220 \mathrm{~mm} \times$ 高さ

$3,200 \mathrm{~mm} \cdots \cdots 2$ 室 3, $000 \mathrm{~mm} \times$ 高さ セレン整流機, 一次電压 $200 \mathrm{~V}$ 二次電圧 $60 \mathrm{kV}$, 容量 $15 \mathrm{kVA}$

(10バッグフィルタ : バッグ.... $300 \mathrm{~mm} \phi \times 3,000 \mathrm{~mm} \mathrm{~L} \times 30$ 本 $\times$ 3 室

沪過面積 $240 \mathrm{~m}^{2}$, 吸引フアン $30 \mathrm{P}$

$340 \mathrm{~m}^{3} / \mathrm{min}, 165 \mathrm{~mm} / \mathrm{WG}$

入場の地並み上にある 4 個の貯鉱ビンに入れ，底 抜き して，鉱石吹き原料は鉱車による手押し，またカラミ吹 き，シリコン吹き原料の場合はコンベヤ輸送により，そ れぞれの電気炉装入ホッパに入れる。電気炉は 2 基連続 操業でNo. 1炉，No. 2 炉ともに 4: 時間ごとにタップする が，抜出終了後の原料装入は 2 回に分けて行なう。産出 カラミはいずれも水砝し，またカラミ吹きで生ずるハー ドヘッドも水砕する。シリコン吹きでは，カラミは発生 しないが，産出する Snメタルおよびフェロシリコンは いずれも別個の砂床に流す。熔錬中の炉内温度は，鉱石 吹きで約 $1,100^{\circ} \mathrm{C}$ ，カラミ吹きで約 $1,200^{\circ} \mathrm{C}$ ，シリコン 吹きで約 $1,400^{\circ} \mathrm{C}$ のごとくそれぞれ温度差があり，かつ 電気炉排煙設備が共有であるため, ガス温度はかなりバ ラっく。

第 1 図より，比較的製錬容易な砂錫を主体とした輸入 錫鉱を近年中止したことがわかるが，これは採算不味の ためである。主製品である粗錫は全量当社直島製煉所に 船積み輸送のらえ，錫電解精製を行ならので，いわば粗 錫は半製品である。したがつて粗錫品位を $97 \%$ 以上に目 標設定し, 特に電解精製に悪影響がない限り多少の不純 物, $\mathrm{Fe}, \mathrm{Pb}, \mathrm{Bi}, \mathrm{Cu}, \mathrm{Sb}$ 等の含有は差支えないので，比較 的不純分の多い買釷錫漳等の電気炉処理も可能となる。 ただし原料錫涬については，その種類も多く，錫ととも に不純物のバラつきも大きいので

（i）受け入れ時における純度の選択制限。

(ii) 熔解時の均一混合

(iii）水あるいは酸リーチング

などの処置を行ない粗錫品質のバラつきを極力防ぐこと にしている。また原料中には Zn も含有し，捕集煙灰中 に逐次濃縮され，製鍊操業を阻害するため回収煙灰の一 定量を定期的に硫酸リーチングして脱亜鉛し操業の内滑 化を計つている。また熔鍊原料中の鉄分については，当 所独特のシリコン吹きにより除去可能であるが，最近原 料中の絶対鉄量の増加が目立ち, 出カラミ率の増加によ

第2図 現状錫製錬系統図 
以上排煙系統の諸改善についても，計画的に実施さ れ，錫鉱熔錬操業に著しい効果があつた。排煙系統の配 置図を第 3 図に示す。

\section{$3 \cdot 3$ 精製設備の改善}

（i） 円盤型自動鋳造機を採用し粗錫鋳造の合理化を 実施した。すなわち $13 \mathrm{t}$ 容量鉄板鍋を新設し，その周辺 に回転式鋳造機を設け35本の鋳型（1 本 $38 \mathrm{~kg}$ 粗錫）を 配列固定し，ポンプアップにより粗錫鋳造後，一定場所 で 5 本 1 組を一挙に転倒せしめ，ホイストにより粗錫積 み込み台車に移転せしめている。

（ii）斜板精製炉を設置し，13 $\mathrm{t}$ 粗錫熔解鍋より発生 する浮涬を側壁シャモットレンガ，炉床鋳物板の斜板型 反射炉で再絞り精製している。

以上はいずれも精製能力の堌強と労務工数の節減を目 的としたものである。

\section{4. 錫製錬今後の問題点について}

わが国における錫需要量に対する国内生産 量の比率 は，昭和 41 年度実績において乾式精錫を含めてわずかに 11\%強に過ぎず，その大部分を輸入に仰いでいる。すな わち国内錫資源は極殞弱というべく，錫の完全回収 は国の経済的見地から考察しても重大であろう。しかも 坑内採掘粗鉱から金属錫までの錫回収率は他の非鉄金属 と比較して，酸化鉱であるだけにはるかに劣ることは周 知の事実である。幸い現在当所に㧍ける錫原料は製鍊能 力ほぼ一杯の確保のもとで操業しているが，遠からず原 料不足の可能性も多分に内蔵している。したがつて選 鉱，製錬分野を通じての収率向上，選鉱廃滓，製錬力ラ ミ等低品位錫鉱の抜本的製鍊法の確立等今後研究開発す ベきテーマは少なくない。

一般に低品位錫鉱 (Sn 0.5 20\%) 処理法としては

(i) 硫化揮発法

(ii) 塩化揮発法

(iii) Hydrometallurgy (iv）その他による方法

に大区分することができよう。いずれについても多数文 献もありそれぞれ特長もあるが，当所における過去の諸 実験から (i), (ii) ともに共通していえることは，還元 雲囲気下における錫揮発条件がその要諦になることであ る。したがつてこの条件を満足する最適の揮発炉の設 計，選択が重要なキーポイントになろう。通常錫精鉣の 還元熔解には反射炉，電気炉等が国内外を問わず一般的 であるが，これと合せて低品位錫鉱に前記のいずれかの 方法をいかに最適に組み合せて操業するかということに より，錫製鍊の合理的処理方策が開発されるのではなか ろらか。

(iii), (iv)についてはその研究範囲も広いが，その一 例として当所では最近低品位錫鉱原料中，比較的高含鉄 錫鉣の入荷があつた（Sn 25\%, Fe 17\%）ので，濃塩酸 処理による一連の実験を試み一応の成果を得ている。

\section{5. 結言}

これまで生野錫製錬所の現況と $2 \sim 3$ の改善例，なら びに今後の問題点の一端を述べてみた。国内錫鉱資源に 限度があること，輸込錫鉱の実現も今後非常に困難を伴 らこと等の悪条件のほか, 年々の人件費増, 諸経費増を 克服するには些細な合理化，改善の積み重ねのほか，低 品位錫鉱の根本的製鍊方法の確立等のテーマが目前に迫 つていると思考する。錫鉱源の面からも到底, 銅, 亜鉛, 鉛製錬等に見られるごとき規模の拡大等によるコストダ ウンは，錫製鍊には簡単に採用困難であるだけに今後と もに関係者の絶大な御支援を損願いするゆえんであり， 同時に製錬技術開発のため，その内容の大小を問わず業 界，学界の御協力をせつに䫝いする次第である。

\section{参考文 献}

1）日本釷業会誌 Vol. 72 , No. 822 , p. 199 200.

\title{
直島製燥所の電気錫製錬
}

\section{Electrolytic Tin Refining at Naoshima Smelter}

\author{
正会員浜部直 彦* \\ Naohiko HAMABE
}

\section{1. 緒言}

沿革 昭和 34 年 10 月従来大阪製煉所で操業してきた錫

* 三菱金属釷業株式会社直島製煉所錫製鍊課長
電解工場を直島製煉所に移設, 昭和 35 年 2 月より電気錫 の生産を開始し現在に至る。本邦最大の電気錫製錬工場 である。

従業員数 22 人 